Tér és Társadalom 14. évf. 2000/2-3. 63-72. p.

Tér és Társadalom

XIV. évf. 2000 2-3: $63-72$

\title{
A MAGYARORSZÁGI IPARI PARKOK FEJLÓDÉSI PÁLYÁI
}

\section{(Development Paths of Industrial Parks in Hungary)}

\section{KULLMANN ÁDÁM}

Magyarországon jelenleg 112 szervezödés rendelkezik ipari park cimmel. Köztük vannak olyanok, amelyek több ezer föt foglalkoztató vállalkozásoknak adnak helyet és országos hírnévre tettek szert. Mások a fejlesztés kezdetén állnak, sok esetben egyetlen vállalkozás sem müködik a kijelölt területen. De nemcsak az ipari parkok pillanatnyi fejlettsége tér el, hanem a potenciális fejlödési pályájuk is különbözik. $A$ tanulmány ezt kívánja feltárni.

\section{Ipari parkok létrejötte Magyarországon}

Az első ipari parkok az átalakulás utáni első években jöttek létre Magyarországon. Gyơrben az önkormányzat osztrák partnerrel (egy ingatlanfejlesztô és egy bank közỏs vállalkozásával) kezdett zöldmezós fejlesztésbe. Székesfehérváron a Videoton ipari parkot hozott létre, hogy így tegye lehetővé az együttmúködést a nyugati vállalatokkal, illetve az átállást a nyugati piacokra. Ugyanitt a Ford beszállítójaként a városba települt Loranger végezte el egy korábbi katonai terủlet rekonstrukcióját. Hamarosan további ipari parkok jöttek létre, szintén az ország északnyugati részén, a nagyobb küllföldi beruházások körül. Így alakult meg, pl. a Szentgotthárdi és az Esztergomi Ipari Park az Opel illetve a Suzuki gyárát magában foglalva, vagy a Flextronics ipari parkja Sárváron. Az évtized közepén aztán már a nyugati határtól távolabb is megkezdődtek a fejlesztések. A Dél-Dunántúlon a két nagyobb megyeszékhely, Pécs és Kaposvár, Észak-Magyarországon az ipari szerkezetváltással küzdő Ózd, az Alföldön a Budapestről autópályán egy óra alatt elérhető Kecskemét járt az élen.

A kormány 1996-ban kezdte meg az Ipari Park Program elökészítését. A Gazdasági Minisztérium 1997-ben kiírta az első pályázatot az Ipari Park címre, amelyet azóta évente megismételt. Az ipari parkok száma 1997-ben 28, 1998-ban 75, 1999ben 112 lett a kormányzati szerepvállalás hatására. Az ipari park cím viselöje, illetve az ipari parkban múködó vállalkozások jogosultak a pályázati rendszerekben valamint a jogszabályokban megfogalmazott feltételek szerint az ipari park minősítéshez kötött támogatások elnyerésére pályázatot benyújtani, illetve preferenciákat igénybe venni. A cím elnyeréséhez többek között megvalósíthatósági tanulmányt és üzleti tervet kell készíteniük a pályázóknak, amely bemutatja, hogy az ötödik év végére az ipari park területén a vállalkozások száma legalább 10, a foglalkoztatottak száma legalább 500 lesz. 
Az ipari park nem könnyen meghatározható gyüjtőfogalom, amelyben a termelésre koncentráló szerveződések (a szüken értelmezett ipari parkok) mellett tudományos és technológiai parkok, logisztikai központok is találhatók (Markó 1999, 4). Az ipari park címmel rendelkező magyarországi szerveződések között is találhatók ilyenek: pl. a lágymányosi Infopark, a Trans-Sped által üzemeltett Logisztikai Szolgáltató Központ és Ipari Park Debrecenben. Az országban számos olyan létesítmény is van, amely ipari park-szerüen müködik, de az ipari park címet nem pályázta meg. Ismert a móri, a rétsági példa. A továbbiakban mégis az ipari park címmel rendelkező szerveződéseket vizsgáljuk, lévén ezekröl állnak rendelkezésre rendszerezett adatok (a Gazdasági Minisztérium gyüjtésében).

\section{Az ipari parkok elemzése régiónként}

Az ipari parkok fejlettsége mindenekelött az ott müködő vállalkozások adataival fejezhetö ki. Bár a fejlettség kétségkívül ennél összetettebb fogalom, az ipari park a vállalkozások müködési feltételeit hivatott elösegíteni, ezért az ipari park is elsösorban a vállalkozások adataival jellemezhetö. A vállalkozások összesített adatai közül tanulmányunkban számukat, foglalkoztatottaik számát, beruházásaik értékét és árbevételüket van módunk bemutatni. A 112 parkról régiók szerinti csoportosításban összesített ábrák készültek.

Az ipari parkok száma

\section{1. ÁBRA}

Az ipari parkok száma régiónként és a cím elnyerésének éve szerint (The Number of Industrial Parks by Region and the Year of Winning the Title)

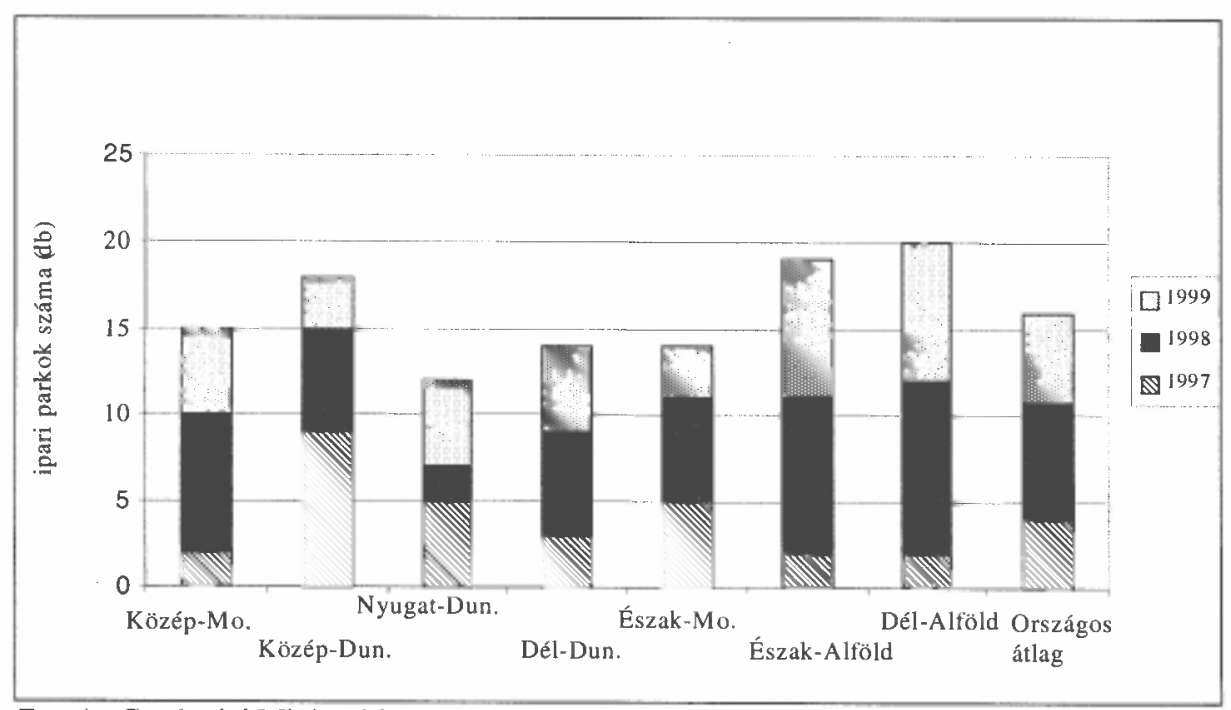

Forrás: Gazdasági Minisztérium 1999. 
Az első ipari parkok többnyire a Dunántúlon, ezen belül is föleg Közép- és Nyugat-Dunántúlon jöttek létre. Az 1997-es ipari parkok fele ebben a két régióban található. 1999 végére ez az országon belüli egyenlőtlenség a parkok szempontjából nem egyszerủen kiegyenlítỏdött, hanem a parkok számát tekintve az alföldi régiók még el is hagyták a nagyobb ipari hagyománnyal rendelkező területeket. Úgy tünik, a kedvezőbb adottságokkal rendelkező területeken kisebb jelentőséget tulajdonítottak az ipari park cím elnyerésének.

\section{Vállalkozások és foglalkoztatottaik száma}

A vállalkozások és foglalkoztatottaik száma az ipari parkok esetében fontos jelzőszám, hiszen a parkok lényege, hogy több vállalkozásnak nyújtsanak közös szolgáltatásokat, és az együttmüködö vállalkozások körén szinergikus hatás alakuljon ki, illetve munkahelyeket teremtsenek a térség munkavállalói számára.

\section{2. ÁBRA}

Az ipari parkokban müködö vállalkozások jellemzōi

(The Characteristics of Firms in Industrial Parks)

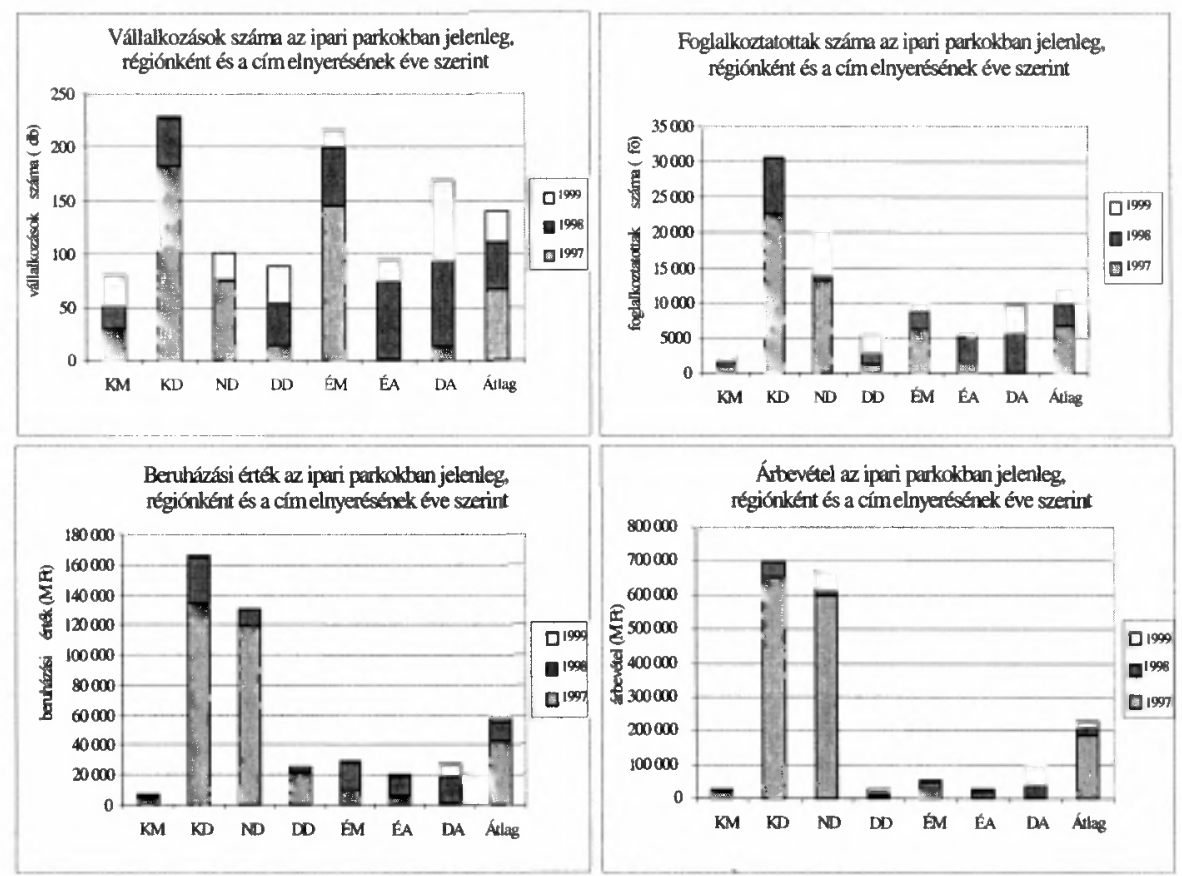

Forrás: Gazdasági Minisztérium 1999.

A 2. ábráról leolvashatjuk, hogy 1997-ben többnyire már olyan pályázók nyerték el a címet, akik több müködő vállalkozással rendelkeztek, míg a késöbbi években jellemzően még a betelepítés elött álló területek jutottak ipari park címhez. A különbség nemcsak az évek, de a régiók között is megfigyelhetó. Kiugró az Északmagyarországi régió értéke, ami nagyrészt egyetlen ipari parknak köszönhető: a 
I

régió ipari parkjaiban található vállalkozások közel 50\%-a az Ózdi Ipari Parkban lelhetö fel.

A Közép- és Nyugat-Dunántúl ipari parkjainak alkalmazotti létszáma is többszörösen meghaladja más régiókét. Köszönhetö ez mindenekelőtt az 1997-ben címet elnyert, de valójában már az évtized elsỏ felében létrehozott ipari parkoknak. Hiába vált egyenletessé azóta az ipari parkok eloszlása az országban, a cím az egyes régiókban lényegesen eltérő szerveződéseket takar.

\section{Beruházási érték és árbevétel}

A beruházási érték és az árbevétel szempontjából még inkább nyomasztó a Közép- és Nyugat-Dunántúl illetve az 1997. évi ipari parkok fölénye, mint az elöző ábrák alapján. Ráadásul az árbevétel koncentrációja a közép- és nyugat-dunántúli ipari parkokban ma magasabb, mint az ipari park program indulásakor. 1997 óta az ipari parkok számát tekintve kiegyenlítődés figyelhető meg az országban, ugyanakkor az itt múködö vállalkozások teljesítménye között bizonyos szempontból tovább nő a különbség.

\section{Az ipari parkok fejlettsége}

$\mathrm{Az}$ egyes régiókban 12 és 20 között van az ipari parkok száma. A régiónként összesített adatok elfedik az egyes ipari parkok fejlettségét. Természetesen 112 ipari parkot nem tud egyenként kezelni ez a tanulmány, ezért a fejlettség alapján csoportokat képeztünk.

Az ipari parkok ,élmezőnyét” (I. csoport) besorolásunkban hét szerveződés alkotja, amelyek a vállalkozások és foglalkoztatottaik számán túl a beruházási érték és az árbevétel alapján emelkednek ki a mezőnyből. Ezek: a Videoton és a Loranger székesfehérvári ipari parkja, valamint a Győri, a Szombathelyi, a Sárvári, a Szentgotthárdi és az Esztergomi Ipari Park. Valamennyi a Dunántúl északi illetve nyugati részén található, és a multinacionális vállalatok már az évtized első felében, a kormány ipari park programja elött letelepedtek itt. Ezek heten a 112 magyarországi ipari park beruházási értékének közel 60\%-át, árbevételének közel 80\%-át adják.

A következő (II.) csoportba azok az ipari parkok sorolhatók, amelyek már most teljesítik a vállalkozások és foglalkoztatottaik számában a központilag támasztott feltételeket, miszerint a szerződéskötést követő negyedik évben az ipari parkok vállalkozásainak száma legalább 10 , foglalkoztatottainak száma legalább 500 lesz. Az említett hét ipari parkkal együtt 22 ilyen volt 1999 végén. Közülük 19 már a szerzödéskötés évében rendelkezett legalább 10 vállalkozással illetve 500 alkalmazottal. Mindössze 4 olyan ipari park van, amely már az Ipari Park cím birtokában jutott el a kritériumok teljesítéséig. Ezek közül is csak egy, Tatabánya ért el jelentős fejlödést (1998-ban vállalkozásainak száma több mint 20-szal, alkalmazottainak száma közel 2000-rel nőtt). Más esetekben szerény mértékủ fejlődés is elég volt a 
kategória-határ átlépéséhez. Megjegyezzük, hogy ellenpélda is akad: egy ipari parkban a szerzödéskötés után csökkent 500 fö alá a foglalkoztatottak száma.

Három további ipari park említhetö, amely - bár egyelöre nem rendelkezik 10 vállalkozással - jelentős teljesítmény-javulást mutatott fel a cím elnyerése óta. A lágymányosi Infopark, valamint a Flextronics nyíregyházi és zalaegerszegi ipari parkja egyaránt 1999-re jutott fogadókész állapotba, és néhány nagyvállalat betelepülésével rögtön meghaladták a küszöbként meghatározott 500 fös alkalmazotti létszámot. (Itt érdemes megjegyezni, hogy a Flextronics sárvári ipari parkja is jó évet zárt 1999-ben: több mint ezer fỏvel nőtt az alkalmazottak száma. Ebben az évben összesen mintegy kilencezer fővel bövült az 1997-98-ban címet elnyert ipari parkok foglalkoztatottainak száma, aminek több mint harmadát adta a Flextronics három ipari parkja.) A lágymányosi, a nyíregyházi és a zalaegerszegi ipari parkkal együtt 26 teljesíti a két kritérium egyikét (12 ipari park rendelkezik 10 vállalkozással, 14 ipari park rendelkezik 500 foglalkoztatottal). Ezek azok az ipari parkok, amelyek viszonylag kis növekedéssel elérhetik a parkszerủ müködéshez szükséges feltételeket (III. csoport).

Az ipari parkok 30\%-ában sem a vállalkozások, sem a foglalkoztatottak száma nem éri el a kritériumot (IV. csoport). További 25\% egyáltalán nem rendelkezik mủködő vállalkozással (V. csoport). Közöttük is megkülönböztethetők azok, ahol még az infrastruktúra kiépítése sem történt meg; ezek a parkok tehát jelenleg még nem alkalmasak vállalkozások fogadására (VI. csoport). Meg kell jegyeznünk, hogy adott esetben olyan ipari parkok is hamar elöreléphetnek, ahol pillanatnyilag nincsenek müködö vállalkozások. Pl. a Tiszaújvárosi vagy a Dorogi Ipari Park esetében már olyan betelepülő nagyvállalkozásról (Jabil illetve Sanyo) írt a sajtó, amely egymaga teljesíti az 500 fős foglalkoztatotti küszöböt. (Csak zárójelben tesszük hozzá, hogy egy-egy beruházás letelepítéséhez nem feltétlenül szükséges az ipari park fejlesztés.)

Az ipari parkok fejlettsége szerint tehát hat csoport képezhető, amelyek. hat egymást követő fejlettségi szintet jelölnek. Igaz, csak kevés ipari park járja végig mind a hat lépcsőt (pl. Győr), mások eleve feljebb kezdik, illetve várhatóan nem érik el a második-harmadik szintet sem.

\section{Területi magyarázó tényezők}

Mint azt már a regionális bontásban készült grafikonoknál láthattuk, az ipari parkok fejlődésében jelentős a területi differenciálódás. Az ipari parkok fejlődése egyelőre beruházás-vonzó képességükön múlik, tehát nagyban összefügg a telephely-minőségi tényezőkkel. A beruházók általában számos szempont alapján választják ki a számukra megfelelő helyet. Ezeknek a szempontoknak egy része nehezen mérhetö, más része csak egyes beruházók számára fontos. Az alábbiakban három olyan szempontot vizsgálunk meg, amelyek a legtöbb ipari park fejlődését meghatározzák. Ezek: az ipari park nyugat-európai elérhetősége, a település népessége, az adott kistérségben a feldolgozóiparban foglalkoztatottak aránya. Előbbiek- 
nek az ország térszerkezetében való meghatározó voltát számos tanulmány igazolta (Nemes Nagy 1998). A feldolgozó-ipari foglalkoztatottak arányának bevonását az indokolja, hogy az ipar speciális igényekkel rendelkezik.

\section{Az ipari parkok fejlettsége nyugat-európai elérhet őségük szerint}

A nyugat-európai elérhetőséget az ipari parkból (illetve azokban a kistérségekben, ahol nincs ipari park, a kistérség központjából) Bécs eléréséhez szükséges idővel jellemeztük, amit egy térinformatikai szoftver állított elö. Bécs gyakorlatilag tetszőleges nyugat-európai várossal helyettesíthető volna a vizsgálatban.

\section{TÁBLÁZAT}

Az ipari parkok fejlettsége nyugat-európai elérhetőségük szerint

(Development Level of Industrial Parks According to the Western European Accessibility)

\begin{tabular}{cccccc}
\hline $\begin{array}{c}\text { Elérhetöség } \\
\text { (perc) }\end{array}$ & $\begin{array}{c}\text { Kistérségek } \\
\text { száma (A) }\end{array}$ & $\begin{array}{c}\text { Ipari par- } \\
\text { kok száma } \\
(\mathrm{B})\end{array}$ & $\begin{array}{c}\text { Ipari parkok } \\
\text { aránya (B/A) }\end{array}$ & $\begin{array}{c}\text { Érett ipari } \\
\text { parkok } \\
\text { száma (C) }\end{array}$ & $\begin{array}{c}\text { Érett ipari } \\
\text { parkok } \\
\text { aránya (C/A) }\end{array}$ \\
\hline $60-135$ & 13 & 6 & $46 \%$ & 3 & $23 \%$ \\
$135-210$ & 39 & 24 & $62 \%$ & 8 & $21 \%$ \\
$210-285$ & 47 & 26 & $55 \%$ & 4 & $9 \%$ \\
$285-360$ & 35 & 21 & $60 \%$ & 4 & $11 \%$ \\
$360-435$ & 16 & 10 & $63 \%$ & 1 & $6 \%$ \\
Összesen & & 87 & & 20 & \\
\hline
\end{tabular}

Megjegyzés: az „ipari parkok száma” és „az ipari parkok aránya” az ipari parkkal rendelkez̋ kistérségek számát és arányát jelöli. Hasonlóan az „érett ipari parkok száma, aránya” az érett, vagyis a minisztériumi kritériumokat teljesítỏ ipari parkkal rendelkezỏ kistérségek számát, arányát jelöli.

Forrás: Gazdasági Minisztérium 1999.

Az 1. táblázat szerint két fö csoport határozható meg az ország nyugati határához mért távolság alapján. Az egyik csoportba azok a kistérségek sorolhatók, amelyek 210 percnél közelebb találhatók, a másik fö csoportban pedig azok vannak, amelyek ennél messzebb fekszenek. A 210 perces határnál (amit a Nagykanizsa-KecskemétHatvan vonal jelöl) jelentősen csökken a sikeres ipari parkok aránya.

Az ipari parkok regionális elhelyezkedése szorosan összefügg az alapítás időpontjával. Míg 1997-ig az ipari parkok elsósorban a Dunántúl északi részén jelentek meg, addig mára a gyenge nyugat-európai elérhetőséggel (és a feldolgozóipari hagyományok hiányával) jellemezhetó alföldi térségek rendelkeznek a legtöbb ipari parkkal. Egy érdekes példa: az 1996-ban elkészült Szabolcs-Szatmár-Bereg megyei fejlesztési program egy ipari park létesitését tủzte ki célul a megyeszékhelyen, nem is a gazdaság vagy az infrastruktúra fejlesztéséhez kötődően, hanem a megye külső megitélésének javítása érdekében - két évvel késöbb hét ipari parkot jelöltek ki a megyében. 


\section{Az ipari parkok fejlettsége a település népességszáma szerint}

A népességszám szerint vizsgálva az ipari parkokat kirajzolódik a folyamat, miszerint az ipari parkok számának növekedésével egyre kisebb települések jutottak ipari park címhez. Míg az 1997-ben címet kapott ipari parkok fele a 30 ezer fönél nagyobb népességszámú településeken található, addig az 1998-99-es pályázati körökön sikeres szerveződések négyötöde már ennél kisebb településekre esik.

Az ipari parkok általában a népesebb városokban lehetnek sikeresek, hiszen itt koncentrálódnak azok a gazdasági és lakossági szolgáltatások, amelyek a vállalkozások mủködéséhez illetve a menedzserek komfortjához nélkülözhetetlenek.

\section{TÁBLÁZAT}

Az ipari parkok fejlettsége a település népességszáma szerint (Development Level of Industrial Parks According to the Population of the Settlements)

\begin{tabular}{cccccc}
\hline Népesség & $\begin{array}{c}\text { Települések } \\
\text { száma (A) }\end{array}$ & $\begin{array}{c}\text { Ipari par- } \\
\text { kok száma } \\
\text { (B) }\end{array}$ & $\begin{array}{c}\text { Ipari parkok } \\
\text { aránya (B/A) }\end{array}$ & $\begin{array}{c}\text { Érett ipari } \\
\text { parkok } \\
\text { száma (C) }\end{array}$ & $\begin{array}{c}\text { Érett ipari } \\
\text { parkok } \\
\text { aránya (C/A) }\end{array}$ \\
\hline Budapest & 1 & 1 & $100 \%$ & 0 & $0 \%$ \\
$100-300$ e fó & 8 & 8 & $100 \%$ & 4 & $50 \%$ \\
50-100e fö & 12 & 11 & $92 \%$ & 4 & $33 \%$ \\
$30-50$ e fö & 18 & 13 & $72 \%$ & 3 & $17 \%$ \\
$20-30$ e fö & 25 & 13 & $52 \%$ & 3 & $12 \%$ \\
$15-20 \mathrm{e}$ fö & 27 & 13 & $48 \%$ & 2 & $7 \%$ \\
$10-15 \mathrm{e}$ fö & 50 & 13 & $26 \%$ & 1 & $2 \%$ \\
$5-10 \mathrm{e}$ fó & 138 & 16 & $12 \%$ & 2 & $1 \%$ \\
$0-5 \mathrm{e}$ fö & 2852 & 12 & $0 \%$ & 1 & $0 \%$ \\
Összesen & & 100 & & 20 & \\
\hline
\end{tabular}

Megjegyzés: az ,ipari parkok száma” és „az ipari parkok aránya” az ipari parkkal rendelkez̋ települések számát és arányát jelöli. Hasonlóan az „érett ipari parkok száma, aránya” az érett, vagyis a minisztériumi kritériumokat teljesítö ipari parkkal rendelkezö települések számát, arányát jelöli.

Forrás: Gazdasági Minisztérium 1999.

A 2. táblázat utolsó oszlopa egyértelmủen igazolja a népességszám és az ipari park eredményessége közötti összefüggést. A sajátos helyzetü Budapest kivételével az egyre nagyobb népességü települések csoportjában egyre magasabb a fejlett ipari parkkal rendelkező települések aránya. (Néhány ipari park - pl. Sajóbábony, Alsózsolca - egy-egy nagyváros szomszédságában fekvö kisebb településen található. Ezeknél meggondolandó, hogy melyik település népességszámát szerepeltessük. Az ilyen esetek száma ugyanakkor alacsony, ezért a trendet nem befolyásolják.)

\section{Az ipari parkok fejlettsége a kistérség feldolgozó-ipari foglalkoztatottainak aránya szerint}

A 3. táblázat kategóriái a feldolgozóiparban dolgozók ezer lakosra jutó aránya alapján lettek felállítva. Jól látható, hogy az ipari parkok annál inkább elérték a minisztériumi kritériumokat, minél magasabb a kistérségben a feldolgozóiparban 
dolgozók aránya. Az összefüggés nem egyértelmü: az ipari park sikerének következménye avagy záloga-e a feldolgozó-ipari foglalkoztatottak magas aránya. Véleményünk szerint az ipari parkok sikeréhez szükséges a feldolgozó-ipari foglalkoztatottak viszonylag magas aránya, mert a betelepülök számára ők jelenthetik a potenciális munkaeröt, míg pl. a mezögazdaságban, kohászatban dolgozók nem.

A három szempont egyesíthető, pl. az ipari parkok egyes szempontok szerinti sorszámának összegzésével. Az így kapott érték alapján nevezhetjük kedvezőnek vagy kedvezötlennek az ipari park településének helyzetét.

\section{TÁBLÁZAT}

Az ipari parkok fejlettsége a kistérség feldolgozó-ipari foglalkoztatottainak aránya szerint

(Development Level of Industrial Parks According to the Share of Employees in the Processing Industry)

\begin{tabular}{cccccc}
\hline $\begin{array}{c}\text { Feld. fogl. 1000 } \\
\text { lakosra jutó } \\
\text { aránya }\end{array}$ & $\begin{array}{c}\text { Kistérségek } \\
\text { száma (A) }\end{array}$ & $\begin{array}{c}\text { Ipari parkok } \\
\text { száma (B) }\end{array}$ & $\begin{array}{c}\text { Ipari parkok } \\
\text { aránya (B/A) }\end{array}$ & $\begin{array}{c}\text { Érett ipari } \\
\text { parkok szá- } \\
\text { ma (C) }\end{array}$ & $\begin{array}{c}\text { Érett ipari } \\
\text { parkok } \\
\text { aránya (C/A) }\end{array}$ \\
\hline $190-135$ & 9 & 7 & $78 \%$ & 5 & $56 \%$ \\
$135-105$ & 11 & 9 & $82 \%$ & 3 & $27 \%$ \\
$105-75$ & 26 & 17 & $65 \%$ & 4 & $15 \%$ \\
$75-45$ & 53 & 36 & $68 \%$ & 8 & $15 \%$ \\
$45-15$ & 50 & 18 & $36 \%$ & 0 & $0 \%$ \\
Osszesen & & 87 & & 20 & \\
\hline
\end{tabular}

Megjegyzés: az „ipari parkok száma” és „az ipari parkok aránya” az ipari parkkal rendelkeß̋ kistérségek számát és arányát jelöli. Hasonlóan az „érett ipari parkok száma, aránya” az érett, vagyis a minisztériumi kritériumokat teljesitő ipari parkkal rendelkezỏ kistérségek számát, arányát jelöli.

Forrás: Gazdasági Minisztérium 1999.

\section{Az ipari parkok csoportosítása}

A bemutatott kétféle csoportosítási mód - vagyis az ipari parkok fejlettsége és a területi magyarázó tényezők - szerint egy kereszttábla szerkeszthetö, amelyben elhelyezhetố valamennyỉ ipari park (4. táblázat). Megfigyelhetjük, hogy a leginkább fejlett ipari parkok a legkedvezőbb háttérrel rendelkezö területeken vannak, bár a legkedvezőbb helyzetü területeken sem csak fejlett ipari parkok találhatók. Fontos észrevenni, hogy a kedvezötlen háttérrel rendelkező térségekben jelenleg nincs olyan ipari park, amely egyszerre 10 vállalkozással és 500 foglalkoztatottal rendelkezne, ugyanakkor alacsony a müködő vállalkozások nélküli ipari parkok aránya is közöttük. Kijelenthetjük, hogy eredményes ipari parkot nehéz megfelelő háttér nélkül létrehozni, ám önmagában a kitünö háttér sem garancia arra, hogy jól müködő ipari park fog kialakulni. A táblázat alapján levonhatjuk azt a következtetést, hogy az ipari park háttereként szolgáló térség eróteljesen behatárolja a parkok növekedési lehetőségeit, így a kedvezőtlenebb térségekben lévő ipari parkok más fejlődési pályát tudnak bejárni. 
Kullmann Ádám : A magyarországi ipari parkok fejlődési pályái Tér és Társadalom 14. évf. 2000/2-3. 63-72. p.

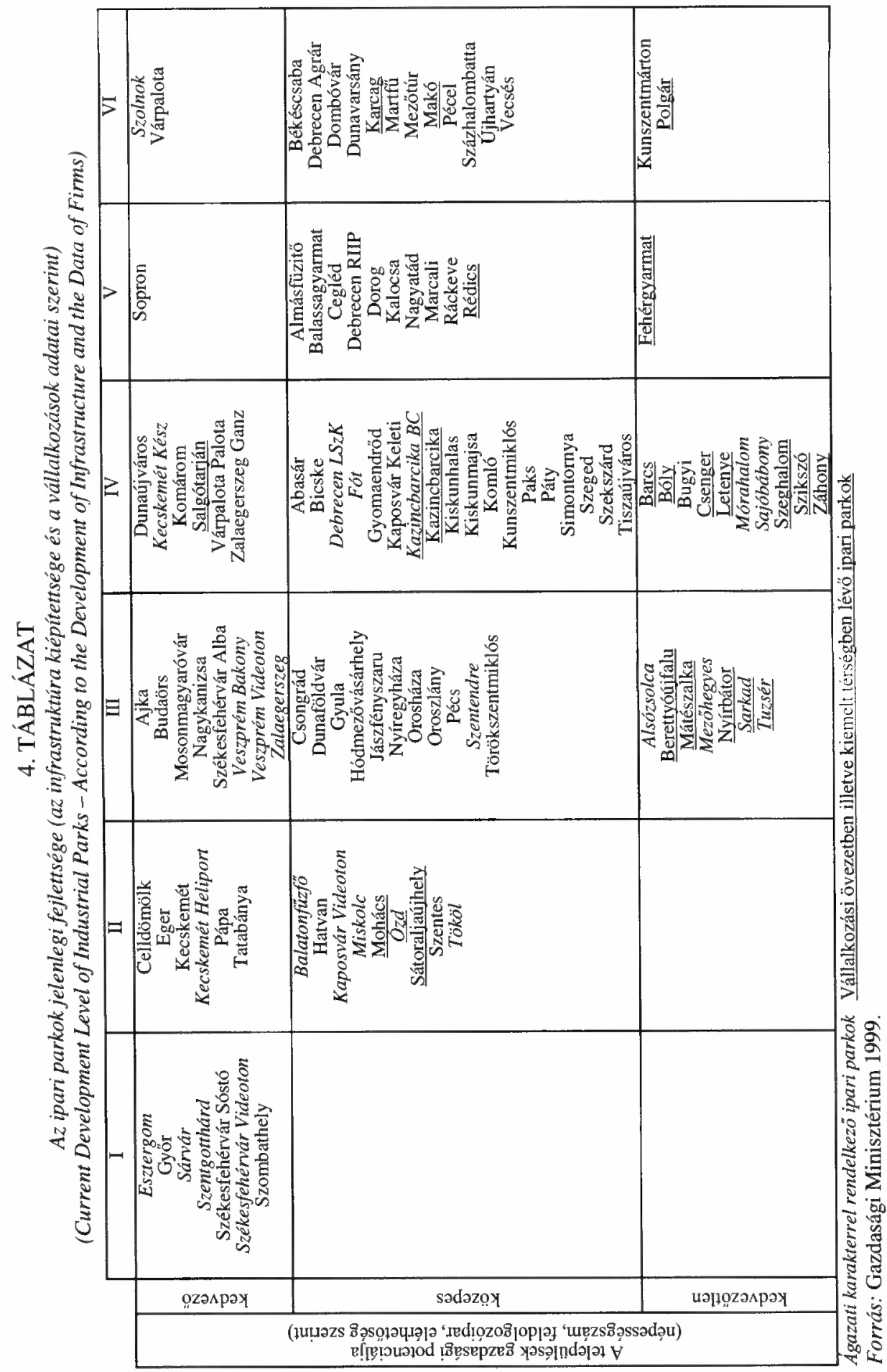


Végül a 4. táblázatban - az ipari parkok egyediségét hangsúlyozandó - dölt betüvel jelöltük meg azokat az ipari parkokat, amelyek ágazati specializációval rendelkeznek, aláhúzással pedig azokat, amelyek a munkanélküliségi ráta alapján meghatározott, a vállalkozási övezetekkel azonos kedvezményeket élvezö kiemelt térségekben találhatók. Utóbbiak - nyilván nem véletlenül - mindenekelótt a kedvezötlen helyzetú településeken találhatók. Ezeknek az ipari parkoknak a létrehozását a rászorultság indokolhatja.

\section{Irodalom}

Markó I. (1999) Az ipari parkok információs rendszere. Budapest, PROMEI.

Nemes Nagy J. (1998) A földrajzi helyzet szerepe a regionális tagoltságban. Munkaerôpiac és regionalitás az átmenet idốszakában. - Fazekas K. (szerk.), Budapest, MTA KTI, 147-167. o.

\section{DEVELOPMENT PATHS OF INDUSTRIAL PARKS IN HUNGARY}

\section{ÁDÁM KULLMANN}

The first industrial parks were established right after the transition in Northern Transdanubia. Seeing their success, the government launched its Industrial Park Programme in 1997. Up to 1999, 112 organisations were awarded the title 'Industrial Park-' All of them have a business plan which plan to locate at least 10 companies with 500 employees altogether in 5 years.

Industrial parks differ in current stage of development. 7 of them account for close to $60 \%$ of the total investments carried out by companies in industrial parks. Further 15 also fulfil the criteria having 10 companies and 500 employees. On the other hand, the number of 'empty' industrial parks is 28 .

The development of the industrial parks is determined by regional characteristics, like Western European accessibility, number of population, rate of employees in manufacturing. Most developed industrial parks can be found exclusively in most favoured regions. 